\title{
Glaux maritima L. (Primulaceae), a new plant species in SE Europe
}

\author{
Antun Alegro, Vedran Šegota*, Nikola Koletić, Nina Vuković, Tihana Vilović, Anja Rimac \\ University of Zagreb, Faculty of Science, Department of Biology, Division of Botany, Marulićev trg 20/II, 10000 Zagreb, Croatia
}

\begin{abstract}
A small population of the circumholoarctic species Glaux maritima L. (Primulaceae) was discovered in the Mediterranean part of Croatia, on the bank of the River Zrmanja. This is the first record of G. maritima in SE Europe, and the third record in the Mediterranean, apart from in Spain and the Asian part of Turkey. It was found on the open riverbank within sub-halophytic vegetation, forming a small population of several dozen erect stems, most probably clonally propagated. The site is characterized by a periodic intrusion of seawater. We propose to classify this species as critically endangered (CR) on a national level due to the small population size and the fragile habitat, which requires active protection and conservation.
\end{abstract}

Keywords: conservation, Dalmatia, halophytes, Lysimachia maritima, rare species, Zrmanja river

\section{Introduction}

The sea-milkwort, Glaux maritima L., belongs to a monotypical genus of the family Primulaceae. Due to new insights in systematics based on molecular techniques, it was proposed to unite the genus Glaux with the genus Lysimachia, and accordingly the species would be named Lysimachia maritima (L.) Galasso, Banfi \& Soldano (Banfi et al. 2005). This taxonomic solution however is still not widely accepted, and many relevant floras published in recent times (e.g. Fischer et al. 2008, Király 2009, Ciocârlan 2009, Jäger 2011, Rottensteiner 2014, Parolly and Rohwer 2016, Euro+Med PlantBase 2017 etc.) have listed the species under the old name.

G. maritima is a perennial herb, with long, creeping, richly branched rhizomes enabling vegetative propagation. Stems are erect or procumbent, rooting at nodes, $5-30 \mathrm{~cm}$ long. The rhizomes contain broadly triangular, membranous leaves. Stem leaves are sessile, entire, elliptic-oblong to obovate, obtuse or acute, in the lower part of the stem decussate, while in the upper part they are spirally arranged, $0.4-1.5 \mathrm{~cm}$ long. Flowers are small, 3-6 mm in diameter, sessile at leaf axils. Calyx is white to purple or pink with obtuse lobes, corolla is lacking. Style is persistent on the capsule, located inside a persistent calyx, $2-5 \mathrm{~mm}$ in diameter (Ferguson 1968, Aichele and Schwegler 2000).

The species is generally distributed on saline coastal areas of the northern hemisphere (Druva-Lūsite et al. 2008), belonging to the circumholoarctic geoelement (Oberdorfer 2001). It occupies brackish or salt marshes and flats, shores of rivers or lakes and wetland margins (Maiz-Tome 2016). In Europe, G. maritima is distributed on the Atlantic, Baltic and Arctic coasts, and very locally in the Western Mediterranean. It also inhabits inland saline soils of Central and Eastern Europe and Spain (Ferguson 1968). According to Euro+Med PlantBase (2017), the only records in the Mediterranean are in Spain and the Asian part of Turkey. Furthermore, the literature shows a complete lack of this species in SE Europe; the only neighbouring country where it occurs is Hungary, and is described there as rare and in decline (Pifkó 2009).

G. maritima is a pioneer halophyte growing on sandyloamy soils, and requires a wet substrate almost up to the surface, but avoiding sites flooded for a longer period. Inland, it occurs only near salty springs and on saline grasslands (Aichele and Schwegler 2000, Oberdorfer 2001). In terms of phytosociology, it is a characteristic species of the alliance Armerion maritimae (order Glauco-Puccinellietalia maritimae - Atlantic salt meadows) (Oberdorfer 2001), and a diagnostic species of the alliance Juncion gerardii Wendelberger 1943 (order Puccinellion limosae Soó 1933 - inland, species-poor saline grasslands) (Kovanda, 1992). On a global level, G. maritima is designated as LC (Least Concern) whereas "the species is widespread, and although possibly declining in parts of its range, it is not thought that any global population decline is likely to meet (or be close to meeting) the threshold for Vulnerable" (Maiz-Tome 2016).

* Corresponding author, e-mail: vedran.segota@biol.pmf.hr 


\section{Materials and methods}

Field work was performed in the Mediterranean part of Croatia, alongside the River Zrmanja, upstream of the town of Obrovac ( $\left.44^{\circ} 11^{\prime} 53.4359^{\prime \prime} \mathrm{N}, 15^{\circ} 41^{\prime} 38.0999^{\prime \prime} \mathrm{E}\right)$ on July $12^{\text {th }}$ 2017. The plant material collected was deposited in herbarium ZA (Thiers 2016). For the purpose of documentation and for enabling public availability of the herbarium sheet, specimens of G. maritima were geo-coded, digitized and included into the online Flora Croatica Database (Nikolić 2017).

Vegetation relevé with plot size $5 \times 2 \mathrm{~m}$ was prepared using the expanded Braun Blanquet scale (Braun-Blanquet 1964, Barkman et al. 1964, Dierschke 1994). Category 2 was subdivided into $2 \mathrm{~m}, 2 \mathrm{a}$ and $2 \mathrm{~b}$. The species nomenclature follows Euro+Med PlantBase (2017).

The most recent IUCN guidelines (IUCN 2017) were used to define the current conservation status of G. mariti$m a$ in Croatia.

\section{Results and discussion}

G. maritima (Fig. 1) is a newly discovered species not only for Croatia, but also for the whole of SE Europe. Its occurrence in Croatia is interesting even in the Mediterranean context, for it was previously known only from Spain and the Asian part of Turkey. The locality is additionally peculiar because this circumholoarctic species reaches here the southernmost border of its distribution. For this reason, the Croatian population is susceptible to climate changes, especially in combination with its small population size, and preference for a very specific and vulnerable habitat, resulting from a complex interference of river, sea and land. We provide detailed information about the distribution, habitat, phytosociology and conservation status of G. maritima, which should be seen as one of the rarest and most peculiar plant species in Croatian flora.

Distribution in Croatia - the only known locality of this species is the left bank of the River Zrmanja, upstream of the town of Obrovac (Fig. 2). It occurs in a narrow belt, not broader than $3 \mathrm{~m}$, very much influenced by the inflow of freshwater from the river.

Habitat and phytosociology - G. maritima was found 12 $\mathrm{km}$ upstream from the river mouth, forming only a narrow strip, growing right next to the river's flow. This strip belongs to a vegetation belt characterised by mixture of wetland and sub-halophytic plants, forming the very first vegetation right next to the river. The whole belt, depending on riverbank micro-relief, is up to $3 \mathrm{~m}$ broad but usually much narrower, and is abruptly replaced by dry, rocky grasslands and shrub dominated by Carpinus orientalis Mill. and Paliurus spina-christi Mill., characteristic for the wider area. The phytosociological relevé on the particular site is: 3 Elytrigia atherica (Link) Kerguélen, 2a Juncus gerardi Loisel., 2m Anacamptis palustris (Jacq.) R. M. Bateman, Pridgeon \& M. W.

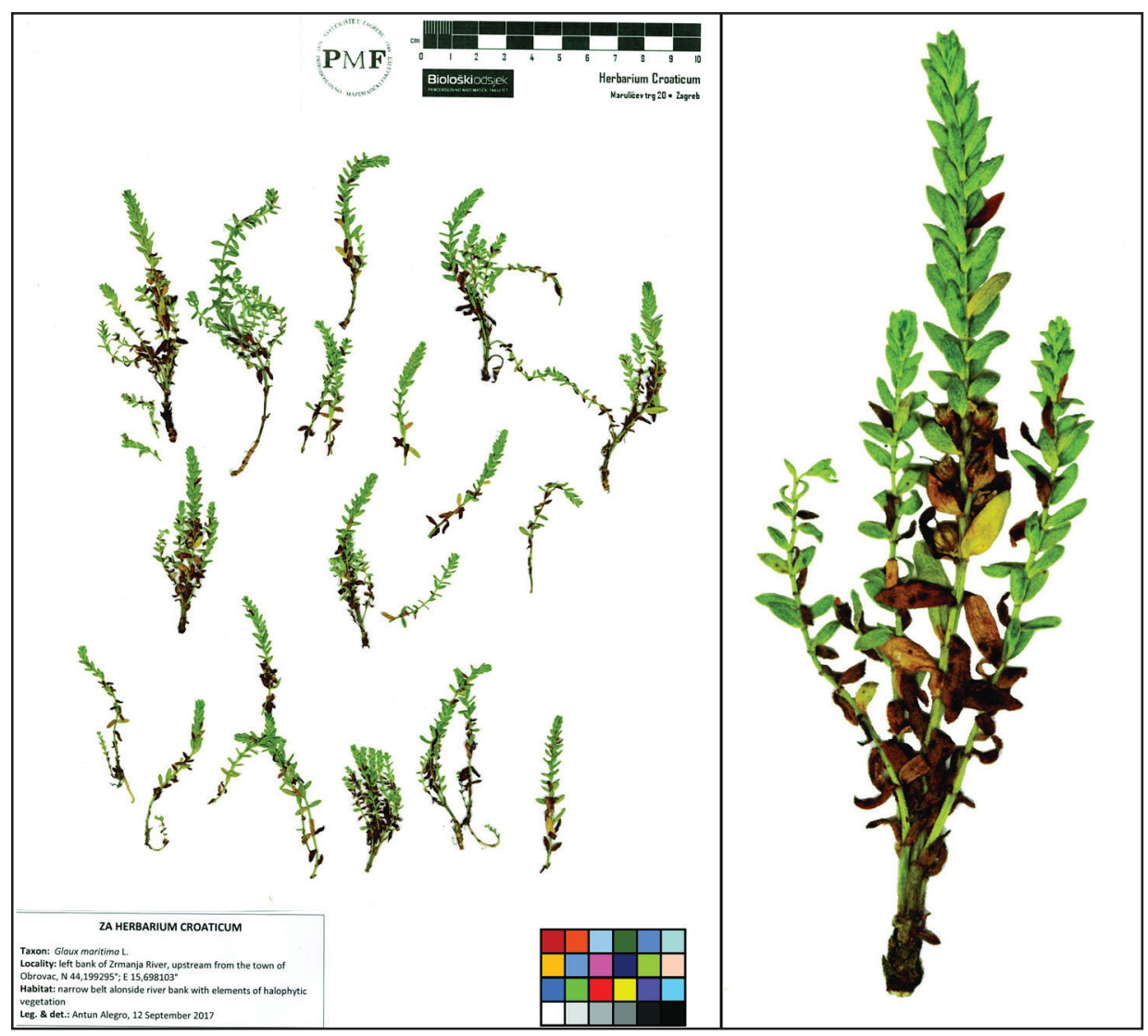

Fig. 1. Herbarium specimen of Glaux maritima L. with enlarged detail of the plant. 


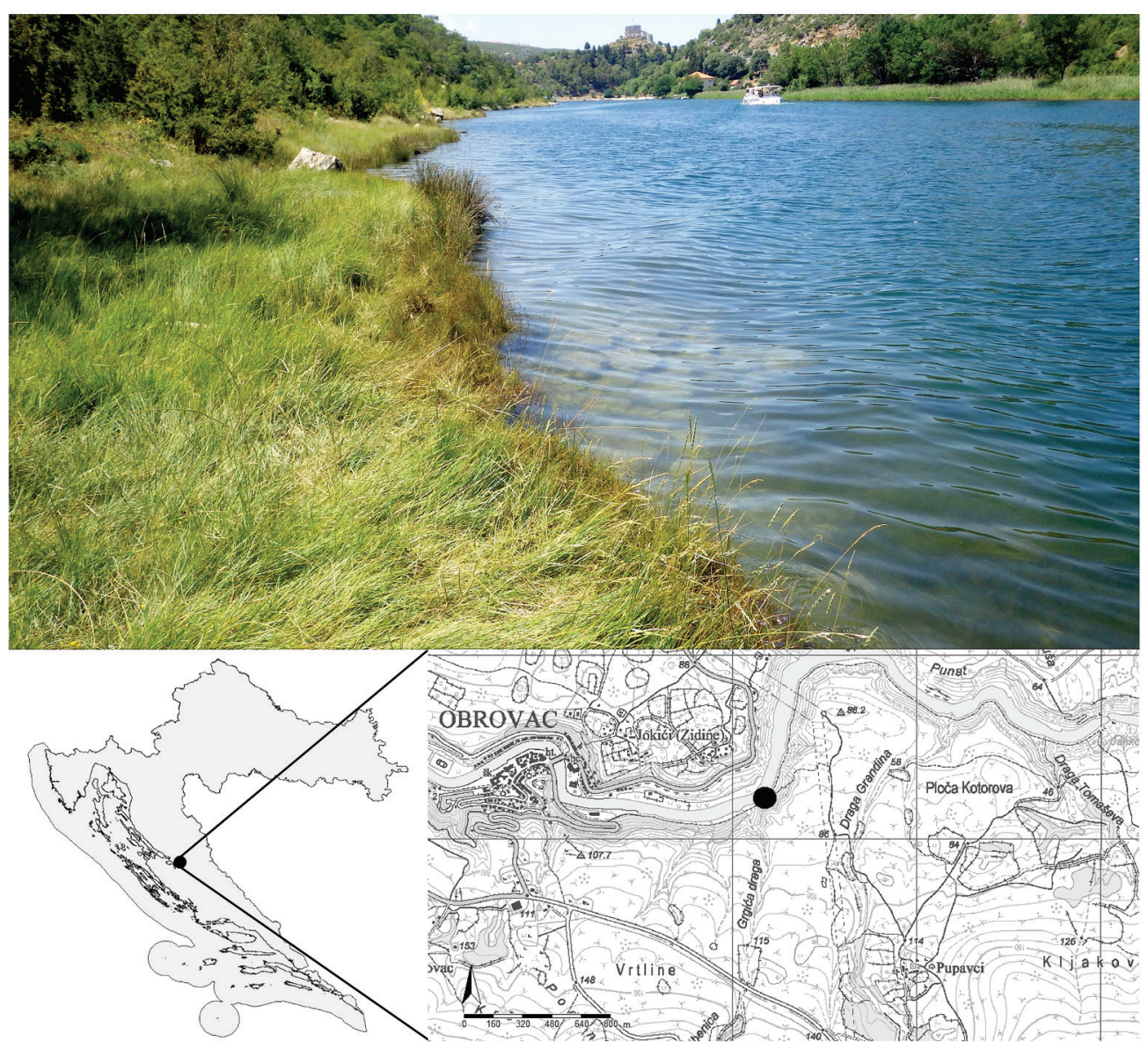

Fig. 2. Habitat (photo by A. Alegro) and locality (black dot) of Glaux maritima L. on the left bank of the River Zrmanja, upstream of the town of Obrovac.

Chase, 1 Glaux maritima L., 1 Triglochin maritima L. (CR), 1 Juncus effusus L., 1 Trifolium medium L., + Sonchus maritimus L., + Carex extensa Gooden. (EN), + Daucus carota L., + Lotus corniculatus L. On a riverbank, the occurrence of vegetation rich in halophytes caused by the intrusion of sea water is an interesting phenomenon. On Zrmanja, this intrusion can reach the first waterfall from the river mouth (Jankovića buk), especially during summer. During winter however, high freshwater inflow blocks the upstream intrusion of salt water (Burić et al. 2007). According to the same authors, the average salinity [PSU] is 20.9 ( $\max .38 .48$, min 0 ). This peculiar hydrology obviously enables the development of vegetation characterized by sub-halophytic elements, even in a very narrow belt on the riverbank. Apart from this combination of fresh and saline water, currently it is difficult to find another satisfactory ecological explanation for the occurrence of G. maritima at this particular locality. The climate of the area is typically sub-Mediterranean, with the mean water temperature of $15.94{ }^{\circ} \mathrm{C}$ ( $\max$. 27.05, min. 6.10) (Burić et al. 2007). Ecologically, these are not the most suitable conditions for the occurrence of this northern species. Most probably, G. maritima can be considered a glacial relict, surviving far away from its optimal environmental conditions. This particular site is of addi- tional value due to the occurrence of two red-listed species - the critically endangered Triglochin maritima and the endangered Carex extensa (Nikolić and Topić 2005).

Conservation status - We observed three patches of $G$. maritima, altogether with up to 50 erect shoots, up to $15 \mathrm{~cm}$ long. The individuals were most probably clonal, due to vegetative propagation by creeping rhizomes. The plants were in good condition, vigorous, with many, but still not completely ripe capsules. The area of occupancy (AOO) and the extent of occurrence (EOO) are both less than $10 \mathrm{~km}^{2}$ in size, and the number of locations is one. At the current moment however, we cannot estimate any changes in the EOO and $\mathrm{AOO}$, because it was not possible to observe, estimate, infer, or project any continuing decline without any previous knowledge about this population. Furthermore, the population is not severely fragmented or undergoing extreme fluctuations. Finally, according to the available criteria (IUCN 2017), the criterion D (very small or restricted population) could be applied for the evaluation of G. maritima. Accordingly, we propose to classify G. maritima as critically endangered (CR) on a national level.

Although currently not detected, we believe that a decline in habitat quality is likely in the near future, due to developing tourism along the Zrmanja River. Moreover, due to 
the small population size, any touristic exploitation or other intervention on the riverbank can easily destroy the existing population of G. maritima. To perform any further estimations, it is necessary to monitor the population/habitat trends in the future.

\section{References}

Aichele, D., Schwegler, H.-W., 2000: Die Blütenpflanzen Mitteleuropas 3. Franckh-Kosmos Verlag, Stuttgart.

Banfi, E., Galasso, G., Soladano, A., 2005: Notes on systematics and taxonomy for the Italian vascular flora. 1. Atti della Società italiana di scienze naturali e del Museo civico di storia naturale di Milano 146, 219-244.

Barkman, J. J., Doing, H., Segal. S., 1964: Kritische Bemerkungen und Vorschläge zur quantitativen Vegetationsanalyse. Acta Botanica Neerlandica 13, 394-419.

Braun-Blanquet, J., 1964: Pflanzensoziologie. Grundzüge der Vegetationskunde. 3. Aufl. Springer Verl., Wien, New York.

Ciocârlan, V., 2009: Flora ilustrată a Românei. Editura Ceres, Bucureşti.

Dierschke, H., 1994: Pflanzensoziologie. Grundlagen und Methoden. Eugen Ulmer Verl., Stuttgart.

Burić, Z., Cetinić, I., Viličić, D., Caput Mihalić, K., Carić, M., Olujić, G., 2007: Spatial and temporal distribution of phytoplankton in a highly stratified estuary (Zrmanja, Adriatic Sea). Marine Ecology 28 (Suppl. 1), 169-177.

Druva-Lūsīte, I., Karlsons, A., Osvalde, A., N̦ečajeva, J., Ievinsh, G., 2008: Photosynthetic performance and mycorrhizal symbiosis of a coastal marsh plant, Glaux maritima, in conditions of fluctuating soil salinity. Acta Universitatis Latviensis 745, Biology, 155-164.

Euro+Med, 2017: Euro+Med PlantBase - the information resource for Euro-Mediterranean plant diversity. Retrieved May 16, 2017 from http://ww2.bgbm.org/EuroPlusMed/.

Fischer, M. A., Oswald, K., Adler, W., 2008: Exkursionsflora für Österreich, Liechtenstein und Südtirol. Biologiezentrum der Oberösterreichischen Landesmuseen, Linz.

Ferguson, L. F., 1968: Glaux L. In Tutin, T. G., Heywood, V. H., Burges, N. A., Moore, D. M., Valentine, D. H., Walters, S. M., Webb, D. A. Flora Europaea vol. 3, 28, Cambridge University Press, Cambridge.

IUCN Standards and Petitions Subcommittee, 2017: Guidelines for Using the IUCN Red List Categories and Criteria. Ver. 13.

\section{Acknowledgements}

We would like to acknowledge our colleague Professor Zrinka Ljubešić for providing a helpful discussion about the hydrology and ecology of the river Zrmanja.

Prepared by the Standards and Petitions Subcommittee. Retrieved December 5, 2017 from http://www.iucnredlist.org/ documents/RedListGuidelines.pdf.

Jäger, E. J., 2011: Rothmaler - Exkursionsflora von Deutschland, Gefäßpflanzen: Grundband, 20. Auflage. Spektrum Akademischer Verlag, Heidelberg.

Király, G., 2009: New Hungarian flora. Vascular plants of Hungary. Determination key. 325, Aggteleki Nemzeti Park Igazgtosag (in Hungarian).

Kovanda, M., 1992: Glaux L. - sea-milkwort. In: Hejný, S.,Slavík, B. (eds.), Flora of Czech Republic 3, 270, Academia, Praha (in Czech).

Maiz-Tome, L., 2016: Lysimachia maritima. The IUCN Red List of Threatened Species 2016: e.T64317602A67730067. Retrieved July 24, 2017 from http://dx.doi.org/10.2305/IUCN. UK.2016-1.RLTS.T64317602A67730067.en.

Nikolić, T., (ed.) 2017: Flora Croatica Database. University of Zagreb, Faculty of Science, Department of Botany. Retrieved August 17, 2017 from http://hirc.botanic.hr/fcd/.

Nikolić, T., Topić J. (eds.), 2005: Red book of vascular flora of Croatia. Ministarstvo kulture, Državni zavod za zaštitu prirode, Zagreb (in Croatian).

Oberdorfer, E., 2001: Pflanzensoziologische Exkursionsflora. 8. Auflage. E. Ulmer Verlag, Stuttgart (Hohenheim).

Parolly, G., Rohwer, J. G., 2016: Schmeil-Fitschen - Die Flora Deutschlands und angrenzender Länder. Quelle \& Meyer Verlag, Wiebelsheim.

Pifkó, D., 2009: Primulaceae [incl. Myrsinaceae, Samolaceae) Primrose family. In: Király, G. (ed.), New Hungarian flora. Vascular plants of Hungary. Determination key, 325, Aggteleki Nemzeti Park Igazgtosag (in Hungarian).

Rottensteiner, W. K., 2014: Exkursionsflora für Istrien. Verlag des Naturwissenschaftlichen Vereins für Kärten, Klagenfurt.

Thiers, B., 2016: Index Herbariorum: A global directory of public herbaria and associated staff. New York Botanical Garden's Virtual Herbarium. Retrieved May 16, 2017 from: http:// sweetgum.nybg.org/ih/. 